\title{
Editor's Note: Adult bone marrow mesenchymal and neural crest stem cells are chemoattractive and accelerate motor recovery in a mouse model of spinal cord injury
}

Virginie Neirinckx', Gulistan Agirman ${ }^{1}$, Cécile Coste ${ }^{1}$, Alice Marquet ${ }^{1}$, Valérie Dion', Bernard Rogister ${ }^{1,2,3}$, Rachelle Franzen ${ }^{1+}$ and Sabine Wislet ${ }^{1{ }^{1+}}$

Editor's Note to: Stem Cell Res Ther 6, 211 (2015)

https://doi.org/10.1186/s13287-015-0202-2

\section{Editor's Note}

Readers are alerted that concerns have been raised regarding Figures 1A and S1 [1]. We will update readers once we have further information and all parties have been given an opportunity to respond in full.

\section{Author details}

'Groupe Interdisciplinaire de Génoprotéomique Appliquée (GIGA),Neurosciences Research Center, Unit of Nervous system disorders andtreatment, University of Liège, Tour de Pathologie 2, Avenue de l'Hôpital, 1,4000 Liège, Belgium. ${ }^{2}$ GIGA, Development, Stem Cells and

RegenerativeMedicine Research Center, University of Liège, Liège, Belgium.

${ }^{3}$ NeurologyDepartment, University Hospital, Liège, Belgium.

Published online: 15 February 2021

\section{Reference}

1. Neirinckx V, et al. Adult bone marrow mesenchymal and neural crest stem cells are chemoattractive and accelerate motor recovery in a mouse model of spinal cord injury. Stem Cell Res Ther. 2015;6:211 https://doi.org/10.1186/ s13287-015-0202-2.

\section{Publisher's Note}

Springer Nature remains neutral with regard to jurisdictional claims in published maps and institutional affiliations.

\footnotetext{
*Correspondence: s.wislet@ulg.ac.be

${ }^{\dagger}$ Rachelle Franzen and Sabine Wislet contributed equally to this work.

'Groupe Interdisciplinaire de Génoprotéomique Appliquée

(GIGA),Neurosciences Research Center, Unit of Nervous system disorders

andtreatment, University of Liège, Tour de Pathologie 2, Avenue de I'Hôpital,

1,4000 Liège, Belgium

Full list of author information is available at the end of the article
}

(c) The Author(s). 2021 Open Access This article is licensed under a Creative Commons Attribution 4.0 International License, which permits use, sharing, adaptation, distribution and reproduction in any medium or format, as long as you give appropriate credit to the original author(s) and the source, provide a link to the Creative Commons licence, and indicate if changes were made. The images or other third party material in this article are included in the article's Creative Commons licence, unless indicated otherwise in a credit line to the material. If material is not included in the article's Creative Commons licence and your intended use is not permitted by statutory regulation or exceeds the permitted use, you will need to obtain permission directly from the copyright holder. To view a copy of this licence, visit http://creativecommons.org/licenses/by/4.0/ The Creative Commons Public Domain Dedication waiver (http://creativecommons.org/publicdomain/zero/1.0/) applies to the data made available in this article, unless otherwise stated in a credit line to the data. 